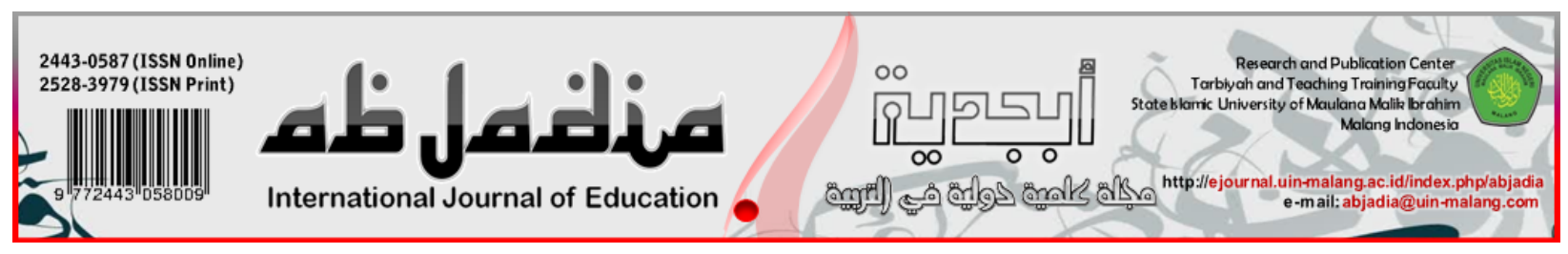

\title{
THE APPEARANCE OF SOCIAL REALITY IN THE DANCER AHMAD TOHARI BY RENE' TA LYSLOFF
}

\author{
Noer Doddy Irmawati ${ }^{1}$, Adhe Puspita Mayasari ${ }^{2}$ \\ ${ }^{1}$ Universitas Ahmad Dahlan Yogyakarta, Indonesia \\ 2 SMP IT Ar Rohmah Yogyakarta, Indonesia
}

\begin{abstract}
Article History:
Received : 2021-01-12

Revised : 2021-01-25

Accepted : 2021-06-24

Published : 2021-06-30
\end{abstract}

\section{Keywords:}

Social Reality, Sociology of Literature,

The Dancer

*Correspondence Address: witha_irmabs@yahoo.com adepuspita5587@gmail.com

\begin{abstract}
This study aimed to describe social reality in Dancer Dukuh Paruk by Ahmad Tohari using sociology of literature theory. Analyzing the data used descriptive method, and collected by library study with identifying novel "The Dancer". From this study can be seen that there is a social reality in Dukuh Paruk. Dukuh paruk is a poor village and backward in every way. In it there are traditions that may be considered by some as taboo and violating norms, but in the village of Dukuh Paruk, they are still strong in holding onto these traditions. The social condition of people who are poor in wealth and knowledge has other social impacts. Rasus and Srintil, who are the main characters in the novel, make Dukuh Paruk village a witness to their love journey which is full of problems and challenges. However, the social problems that hinder them are not only due to their inability to unite their love, but also because of the many environmental factors that surround them. In Dukuh Paruk village, there are many social realities which represent the life of Dukuh Paruk Village which is small but has complex problems. This phenomenon caused by some aspects such as poverty and lack of knowledge in society. Some social reality founded in this story started from poverty, sorcery, tyranny, love, prostitution, pre-wedding sex, trickery, social jealousy and sexual abuse.
\end{abstract}

\section{C) Introduction}

Darmono in Najid (2009: 9) explained that literature is a reflection of life, literature is crystallization of values and life experiences. Literature presents a picture of life and life is a cultural reality. Sangidu (2004: 43) stated clearly that literary works are the author's response to the world around them or social reality. Literary work is a new world created by the author. The new world is a combination of social realities that exist within the author's environment and from outside the author's environment in expressing his thoughts and desires. In making literary work, the author does not only rely on the observed social reality, but the author also involves what is he feels and what interprets about life, as well as the author's creative process that comes from within the author himself. Djojosuroto (2006: 77) has an understanding that literature in an author's 
reflection on life and life combined with a style of imagination and creation supported by his experiences and observations of life. The creation of a literary work cannot be separated from the situation and condition of society at the time of work literature was created. One of the literary works that have many similarities with existing facts in the real world is a novel. The content in the novel is certainly inspired by the real world imagined by the author. The experience and the environment around the author is a source of inspiration in the creative process of making a novel. The author processes social reality into a work of fiction.

Social reality in the novel The Dancer describes a series of stories that occur in a society and is written nicely by the author. The novel written by Ahmad Tohari and translated in English by Rene' TA Lysloff, this story describes the social reality that exists in a village called Dukuh Paruk, in this small village there are many social problems such as poverty, prostitution, premarital sex, arbitrariness and so on. This makes the story interesting to study, especially the aspects of social reality by using the sociological theory of literature. This research will provide a clearer picture of the condition of the Dukuh Paruk community as stated in the story The Dancer. The problem that will be discussed in this research is what social realities are contained in The Dancer story? The purpose of this research is to compile a research paper that contains the social reality in The Dancer by Ahmad Tohari.

\section{[Deoretical Support}

Sociology in literature is a combination and different systems of knowledge. Sociology is a field of science that makes society as a material object and social reality as a formal object. In a sociological perspective, social reality in a community understood in three main paradigms, namely social facts, social definition, and social behaviour paradigms.

Semi (1984: 52) concluded that sociology of literature is an approach that has an orientation to the author. Sociology of literature is part of literary critics it specializes in studying literature by paying attention to social aspects. The product of the review itself can be classified into the product of literary critics. Ratna (2003: 25) said that the sociological analysis of literature intends to explain that literary works are essentially social fact that not only reflect the social reality that occurs in the society where the works is born but also the author's response to that social reality. Sociology of literature is research on literary works by considering the involvement of its social structure, so that sociology of literature research, both in the form of scientific research and practical applications, is carried out by describing, understanding, and explaining the elements of literary works in relation to changes in the social structure happening around him. Waluyo (2006: 1) explained that prose fiction is divided into three, namely romances, novels, and short stories. The three literary genres are actually not much different, they are only affected by differences in the length of the story and the depth of story. 
However, all three have in common the building blocks. Novel and short story. Also the romance is often distinguished by people, although of course this is theoretical. Goldman (Faruk, 1999: 29) defined that a novel is as a story about which degraded by the authentic values carried out by problematic heroes in a world that is also degraded.

Social reality is an event that really happens in society. This term is used to denote an unusual phenomenon in society. This is born from human behaviour in their social life and forms social symptoms into a certain fact or condition.

\section{[Q] Method}

In doing this research the writer used descriptive method in analysing the data. Setyosari (2010) explained that descriptive research is research that aims to explain or describe a situation or event, an object in the form of a person or everything related to variables that can be explained either by numbers or words. Semi (1993) said that qualitative research was conducted by not prioritizing numbers, but using a deep appreciation of the interaction between concepts being studied empirically. Endraswara (2011: 15) stated that the important features of qualitative research in literary studies include research descriptive, the meaning was broken down in the form of words or pictures if necessary, not in the form of numbers. The process prioritizes contains many interpretations, inductive analysis and meaning in the mainstay. This type of research is literature research that describes social reality in the novel The Dancer by Ahmad Tohari.

\section{ز⿳亠丷厂巾}

The social reality contained in Ahmad Tohari's The social reality contained in Ahmad Tohari's novel The Dancer can be seen in the following description.

\section{Poverty}

Natadipura (2012: 1) said that poverty is a social reality that is often found in people's lives. The problem of poverty is caused by various factors. Poverty is a condition that is associated with needs, difficulties, and shortcoming in various situation of life.

Poverty is considered a social problem, if the economic differences of the community members are strictly determined. In a society that is modest in structure and organization, poverty is not a social problem because they think that everything is predestined so that there is no attempt to overcome it. This is illustrated by the poverty of the community that occurs in Dukuh Paruk. The children in the village do not consider poverty as something that must be mourned and complained about. They think that the poverty is something normal and it makes them learn fight for life by working hard. Tohari (2011: 10) wrote that there are three boys were struggling to pull out a cassava stick in the edge of the village. However, the three of them are still too weak to divert the grip of the cassava roots buried in lime soil. Dry and petrified. They gasped for breath, but the cassava stalk remained upright in its place. 
Poverty teaches the children of Dukuh Paruk not to complain and always adjust to existing conditions. While other children spend their evenings watching television or doing homework in a comfortable place, the children at Dukuh Paruk spend their evenings curled up in sarongs on bamboo hall waiting for morning to come. They are not familiar with the shows or other types of entertainment. On Tohari, (2011: 10) written that on the night no Dukuh Paruk's child left the yard. After finishing a plate of cassava rice, they prefer to roll up in a sarong, sleep on top of bamboo stalls. They would wake up tomorrow morning ehen sunlight broke through the gaps in the wall and stung their skin. Even though the children in Dukuh Paruk eat only cassava rice, they still enthusiastic when meal time comes, this is because they never feel really full. When is time to eat the children in Dukuh Paruk they run outside to tear the leaves which will be used as eating mats, only some of them eat using plates.

\section{Shamanism}

The practice of shamanism has been frequently encountered in the community for a long time. In ancient times, shamans worked more in rural areas with minimal knowledge and in community health service centers. The public society who comes to shamans is to treatment or "pelet". In the tradition of Dukuh Paruk, a dancer who wants to be idol. Gets a call to stage and admired by many men mush has "pekasih" a kind of implant used to increase one's attractiveness. It is something normal and general applies in society. Therefore, as the grandfather of Srintil, Sakarya naturally wanted his granddaughter to become a famous dancer who was in demand by many people. He asked Srintil to meet Kartareja and his wife who were known as an experts of shamanism in Dukuh Paruk. In Tohari (2011: 16) Sakarya said that her granddaughter doesn't seem at good at throwing "sampur". So, he asked Kertareja as an expert of shamanism to give "pekasih". Srintil's beauty and ability to dance are considered of "pekasih" from Kertareja and his wife. This has made people more trusting in their greatness. People trust in the ability of Kertareja and his wife. In Tohari, (2011: 82) stated that people in Dukuh Paruk was very believe after Srintil became famous dancer

\section{Tyranny}

To be arbitrary is to act at will without regard for the other rights. Abuse can be interpreted as an act of someone who uses the advantages of position, wealth, power, intelligence or anything else to fulfill all his wishes by ignoring all existing rules. Rasus's mother, who died because of "tempe bongkrek" poisoning never been able to find her grave, as a child Rasus was eager to know his mother, but no one could give a definite answer about his mother. In fact, some people from Dukuh Paruk think that Rasus's mother has been the target of abuse by certain people. The body of his mother was used as a research material to determine the cause of her death and the levels of poison that caused it. It is of course injustice for Rasus. He has the right to know about his mother. But this does not apply to the poor and stupid residents of Dukuh Paruk. In Tohari, (2011: 
35) there was script said that mother's blood is checked to find out how much "bongkrek" poison is quite deadly. Rasus imagined that almost all part of Mother's organs are chopped. Then put under a microscope lens or examined in a variety of complex laboratory equipment. Finally, the body of his mother was already messy and smelled of formaldehyde, was planted. Rasus don't know where is his mother.

Kertareja and his wife become dancer shamans as well as foster parents for Srintil, they play a big role in all their affairs. Kartareja and his wife have the right to decide every big offer that comes to Srintil. This causes Srintil to work hard to perform dancing at every opportunity, especially when the harvest season arrives, many offers come to him. Srintil's job was not enough because during the day she had to serve the man who ordered her. All these things fall under the authority of Kartareja and his wife. There was stated in Tohari, (2011: 125) that dancer shaman likes to organize all his affairs, often even wants to control the assets of his foster children. "That's an old story. A dancer is often seen as a domestic animal by his landlord. Behold, in the season of the holy man or the period of off-harvest; Dancer takes the stage every night. During the day she must serve the man who wants her. Meanwhile, the one who manages all affairs, especially financial matters, is the dancer shaman. As dancer shamans Kartareja and his wife are the ones who know best about all of Srintil's affairs. As Dancer, Srintil's job is only to dance and serve the men who want it. The income affairs he received from that job are not known. The ones who knew about this were the Kartareja husband and wife. The income that Srintil receives as a hard-working person is often less than that of his landlady, this arbitrariness is due to Kartareja feeling that he has become a person who contributed to Srintil's career. He considered Srintil's success as the fruit of his intelligence and knowledge. In Tohari, (2011:140) stated that Kertareja and his wife are dancer shamans. They are the ones who know all about dancer and they use their knowledge and status as a basis for their livelihood. From the show fee they take a part that is sometimes bigger then the portion of Srintil.

\section{Love}

Love is an emotion of intense affection and personal attraction. In context the philosophy of love is the virtue which inherits all kindness, feelings of compassion and compassion. The love story depicted in the novel Tohari, is shown in the characters Srintil and Rasus. Rasus, who is feeling love for Srintil, makes various efforts to attract the attention of his idol girl. He also does cunning methods such as stealing papaya fruit from people's fields to give to Srintil, this is only so that Srintil will look at him for a moment. Maybe this is what some people say that love sometimes forces a person to do things that are unreasonable. On Tohari, (2011: 37) stated that Rasus seems that Srintil doesn't feel the need to pay attention to him or anyone because everyone else has noticed. And Rasus think Srintil's attention was lost in his heart. Then Rasus found a sneaky way to get Dukuh Paruk's dancer attention back. A papaya he stole from people's fields. The feeling of love that Rasus feels for Srintil makes every meeting with Srintil very 
meaningful. For Rasus, being able to enjoy Srintil's smile is a very valuable opportunity for him. Srintil's smile can make his heart race harder and that feeling is something to make him happy. On Tohari, (2011:37) stated that when Rasus meet Srintil, Rasus will have a heartbeat if he receives a smile with such a golden flash of light. a gentle glow emanated from his gilded fangs. Anyone with a taste for Dukuh Paruk will have a heartbeat if he receives a smile with such a golden flash of light.

Rasus's love for Srintil has led him to do things that can bring him closer to the girl like stealing papaya for Srintil, but Srintil's attention did not last long, Srintil who started appearing as a dancer has many fans who are always waiting for his appearance. This situation makes Rasus feel jealous because he thinks Srintil is no longer his alone. This caused a feeling of disappointment in Rasus' heart who could not accept this fact. One sign of love is jealousy in his heart to the person he loves. This jealousy arose because of the fear in Rasus that he would lose Srintil. On Tohari, (2011: 39) stated that since the papaya event, Rasus felt Srintil was getting away. He often taught that Srintil's beauty is not his mine. The smooth sideburns on Srintil's cheeks that were more pleasing to the eye were not his mine. Rasus thought that when Srintil smiled is not for him, but for everyone. But Rasus still disappointed because he cannot longer play with Srintil. Srintil, who has become a dancer, also serves every man who wants her by receiving payment, but this does not apply to Rasus because he has special feelings for the young man. Even though he had to serve Rasus, Srintil never demanded payment from Rasus like he did other men. It shown on Tohari, (2011: 89), stated that even though Srintil is always angry at being called a harlot, he knows very well every house that can be rented for obscene acts. Srintil proved her words that from Rasus, Srintil does not expect money. Srintil is a dancer who is also at the same time a lust for men who want her, it doesn't make her feelings as a normal woman who wants the love of the man she loves just disappear. The deep love that Srintil felt for Rasus was not replace like what she wanted. Rasus left him with a reason that he didn't want to destroy Srintil's career as a dancer. This fact hurt Srintil deeply. On Tohari, (2011: 141) stated that no matter how much she is a Dancer, Srintil feels she has no difference with other women. She has special feelings for a certain man and feels like she should have a chance to choose. It is Srintil's luck why the man chosen to be the mouth of all her heart and feelings is Rasus; he who had reject her and abandoned her in a painful way.

\section{Prostitution}

The Dukuh Paruk tradition requires a dancer to do a "bukak klambu" event, which is the tradition of releasing the virginity of a dancer for a man who is able to meet the requirements set by the "dukun" dancer. These requirements are usually in the form of a number of assets that must be fulfilled by men who are interested in participating in the competition. This is a kind of prostitution wrapped in tradition, but in Dukuh Paruk society it is not taboo or violating norms, those who are poor in knowledge and religion do not realize that this kind of tradition is actually the practice of disgraceful prostitution 
if it occurs in another place. On Tohari, (2011:51) stated that rom the people of Dukuh Paruk known the last requirement that Srintil must fulfill is called the "bukak klambu". Stand up the hair on my neck after knowing the kind. It is a kind of contest, open to any man. What is celebrated is the virginity of a dancers. Men who can hand over an amount of money as determined by the "dukun" dancer, are entitled to enjoy the virginity. Kartareja, who is Srintil's pimp, has to pay to make the "bukak klambu" night something special and interesting. The large number of enthusiasts has fulfilled the requirements set by Kartareja. Kartareja also required a gold ringgit for Srintil's virginity. Kartareja tries to make up Srintil's bedroom by buying a bed complete with new pillows and mosquito nets. This was done with the aim that the man who won the competition later felt comfortable sleeping with Srintil. It is looked on Tohari, (2011: 52) stated that long ago Kartareja had determined that at night Srintil should lose her virginity. For that Kartareja he had to pay for it. He has sold three goats to the market. From the sale, he bought a new bed, complete with pillows and mosquito nets. In this bed, Srintil will give her virginity for the man who won the competition. Rasus, who had feelings of love for Srintil, was very disappointed by the "bukak klambu" event. The girl whom he adores will be enjoyed by a rich masher because able to meet the requirements of one ringgit of gold. The thing that be sad for Rasus is actually the figure of the mother he has been looking for is in Srintil. On Tohari, (2011: 53) stated that for Rasus Srintil's bed will be a place for Srintil to carry out the night, no more than a place of massacre. Or even more disgusting. There three more days will take crushing and slaughter. Rasus is not speaking at all for sexual interests or the like. There, inside the mosquito net brackets visible from where he was standing, there would be the destruction of the "mustika" which he had so much respect for. After the opening at night, Srintil is no longer holy. About her losing her virginity, Rasus don't feel that much. But Srintil as the mirror where he looked for Mother's reflection became diffuse and even shattered.

\section{Pre-Wedding Sex}

Sex before marriage is very taboo in terms of religious and social norms, however this is not the case in Dukuh Paruk, a village where premarital sex is legal without any sanctions. Srintil, who is still a child, already knows how to attract the man she wants. Rasus, whom he loved, could not afford to have herself because he did not have one ringgit of gold as a condition for obtaining her virginity. Srintil only wanted Rasus. Stated on Tohari, (2011: 66) that Rasus didn't move an inch when Srintil embraced me, kissed me. Her breath sounded fast. Radsus felt his palms sweat. When Rasus turned to the side he saw that Srintil's face was tense. Actually Rasus don't like Srintil like that. Although he is inexperienced, but Rasus can guess Srintil is gripped by lust. Without removing the circle of his arms around my shoulders, Srintil turned her head around. He was worried that someone else was around the place. Actually, Srintil shouldn't be too suspicious. The croton and frangipani trees surrounding the Dukuh Paruk cemetery form a very tight fence. Srintil let go of his embrace. Then Rasus understood what Srintil was doing so that she could take off her clothes easily. 
Rasus hates the "bukak klambu" event. Actually, Srintil didn't like it either. She didn't want to give her virginity to a man she didn't love. He just wanted to give it to Rasus, the young man she had loved. Even though Rasus had previously rejected Srintil's wish, at that time Srintil begged Rasus not to refuse his request. As a man who also loves Srintil, Rasus finally fulfills Srintil's wish. On Tohari, (2011: 76) stated that Srintil thought be better give her virginity to Rasus. She wants Rasus not refuse it. Rasus can't answer a word. His throat feels choked. Because it's dark he can't see very well. But he felt Srintil let go of her arms, then was busy taking off his clothes.

\section{Trickery}

The contest about Srintill's virginity turned out to be of great interest to young people, this caused the cunning of Kartareja and his wife to want to get a bigger profit than the predetermined value of the competition. They both later tricked Dower and Sulam, who were very interested in the "bukak klambu" contest. Mrs. Kartareja makes Dower half drunk and Sulam gets so drunk that he falls asleep. When Sulam fell asleep Mrs. Kartareja told Dower to enter Srintil's room and satisfy his lust. When he finished carrying out his wish, Dower felt he had won the competition. Another time Sulam wakes up and rushes to Srintil's room to carry out his wish to sleep with Srintil because he has handed over a golden ringgit to Kartareja in accordance with the manipulated conditions. He did not realize that Dower had preceded him because at that time he had fallen asleep drunk. This was done by Kartareja and his wife so that he could take Dower's treasure at once. Supported on Tohari, (2011: 77) Mrs. Kertareja offer Srintil to service Sulam to. She said Srintil will be the only child who has gold ringgit in this Paruk Hamlet.

The case that Srintil fell in love with Rasus deeply troubled Mrs. Kartareja and her husband. A dancer should not fall in love with any man on the contrary, it is men who should be crazy about the dancer. In addition, if Srintil falls in love with Rasus and intends to marry Rasus, it means that her career as a dancer will end and her source of income will also die, of course this is very worrying for Mrs. Kartareja and her cunning husband. On Tohari, (2011: 115) stated that if there is someone who is most worried about Srintil's situation, of course it is Mrs. Kartareja with her husband. They really don't want their children to fall in love with Rasus or any other boy. This is all the more so if Srintil thought about a household she wanted to build. Their dignity as shaman dancer was at stake, and their fertile source of income will loss.

\section{Social Jelousy}

Srintil, who is selling well as a dancer as well as a calling woman, gets a lot of wealth from her work, gold jewelry weighing tens of grams is a common sight in her appearance, this has caused jealousy from the women who saw her, they gossiped about the jewelry Srintil wore and how to get it. On Tohari, (2011: 81) stated that the other women thought that just a few months as a dancer, Srintil already has a gold bracelet in her hand. The pendant of the necklace is also a gold ringgit. 


\section{Sexual Abuse}

Srintil is known to everyone as a call girl who can sleep with any man. This causes traders in the market to keep trying to steal Srintil's attention by offering Srintil their wares for free. This was done in the hope that Srintil would fulfill their desires. When Srintil was shopping at the market, a soap seller teased Srintil and tried to hug Srintil's hips. Srintil has been made the object of sexual harassment by men by allowing men to speak impolite and treat themselves with disrespect. Likes on Tohari, (2011: 83) Simbar as a shop seller said that he knows that in Dukuh Paruk people rub stones against their bodies when they are bathing. But Srintil don't deserve it. Take a shower with Simbar's soap. Don't pay if Srintil open the door to his cubicle tonight by stretched out towards Srintil's hips.

Not only a trader who tries to take advantage of Srintil's body, another seller, Babah Pincang, teases Srintil by trying to pinch Srintil's cheek. Srintil, who has been accustomed to dealing with misheard men, just let the abuse happen to her. On Tohari, (2011: 83) stated stated that as well as Pak Simbar, Babah Pincang, his hands are itchy. Not Srinti's hips what he digits, but his cheeks. This time Srintil didn't try to refuse.

Rasus as a man who loves Srintil also doesn't dare to see her anymore. If he doesn't have money. Rasus thought that to be able to sleep with Srintil only people who have money. This made Srintil feel harassed. Rasus turns out to have judged it with money like other men even though in his heart Srintil Rasus has a special place that is different from any other man. It seen on Tohari, (2011: 89) Rasus said that forever Rasus don't want to see Srintil again unless he has money.

\section{Conclusion}

Dukuh paruk is a poor village and backward in every way. In it there are traditions that may be considered by some as taboo and violating norms, but in the village of Dukuh Paruk, they are still strong in holding onto these traditions. The social condition of people who are poor in wealth and knowledge has other social impacts. Rasus and Srintil, who are the main characters in the novel, make Dukuh Paruk village a witness to their love journey which is full of problems and challenges. However, the social problems that hinder them are not only due to their inability to unite their love, but also because of the many environmental factors that surround them. In Dukuh Paruk village, there are many social realities which represent the life of Dukuh Paruk Village which is small but has complex problems. Reality social issues contained in the novel Dancer Dukuh Paruk include, 1) poverty, 2) shamanism, 3) arbitrariness, 4) falling love, 5) prostitution, 6) premarital sex, 7) cunning, 8) social jealousy, and 9) sexual harassment. 


\section{Bibliography / مراجع}

Aditya, Rahadiyanti and Achmad Basari. 2013. The Ideology of Translation of Cultural Terms Found in Ahmad Tohari's Novel "Ronggeng Dukuh Paruk" into Its English Version "The Dancer" http:/ / eprints.dinus.ac.id/8193/1/jurnal_12158.pdf (retrieved on November 6, 2020).

Djojosuroto, Kinayati. 2006. Analisis Teks Sastra dan Pengajarannya. Yogyakarta: Penerbit Pustaka.

Endraswara, Suwardi. 2011. Metodologi Penelitian Sastra; Epistemologi, Model, Teori, dan Aplikasi. Yogyakarta: Caps.

Faruk. 1999. Pengantar Sosiologi Sastra. Yogyakarta: Pustaka Pelajar.

Najid, Moh. 2003. Mengenal Apresiasi Prosa Fiksi. Surabaya: University Press.

Nurgiyantoro, Burhan. 2005. Teori Pengkajian Fiksi. Yogyakarta: Gadjah MadaUniversity Press.

Ratna, Nyoman Kutha. 2003. Paradigma Sosial Sastra. Yogyakarta: Pustaka Pelajar.

Sangidu. 2004. Penelitian Sastra: Pendekatan, Teori, Metode, Teknikdan Kiat. Yogyakarta: Seksi Penerbitan Sastra Asia Barat. Fakultas Ilmu Budaya. Universitas Gadjah Mada.

Semi, M. Atar. 1984. Kritik Sastra. Bandung: Angkasa.

Semi, M. Atar. 1993. Metode Penelitian Sastra. Bandung: Angkasa.

Semi, M. Atar. 2003. The Dancer. Translated by Rene TA. Lysloff. Jakarta: The Lontar Foundation.

Setyosari, Punaji. 2010. Metode Penelitian Pendidikan dan Pengembangan. Jakarta: Kencana

Sumaryadi, I Nyoman. 2015. Teori Ilmu Sosial. https://www.slideshare.net/DIP_3/teoriilmu-sosial-s3-615-prof-nyoman (retrieved on November 6, 2020).

Tohari, Ahmad. 2011. Dancer Dukuh Paruk. Jakarta: Gramedia Pustaka Utama.

Waluyo, J Herman.2006. Pengakajian dan Apresiasi Prosa Fiksi. Surakarta: UNS Press. 